\section{HÁLAPÉNZ A SZÜLÉSZETBEN - EGY KVALITATÍV VIZSGÁLAT EREDMÉNYEI}

Sági Csilla (a Budapesti Corvinus Egyetem Közgazdálkodás és Közpolitika szak volt hallgatója, jelenlegi munkahelye: Nemzetgazdasági Minisztérium), Baji Petra, PhD (Egészségügyi Közgazdaságtan Tanszék, Budapesti Corvinus Egyetem)

A cikk Sági Csilla (2016) „Hálapénz a szülészet-nőgyógyászat szakterületén, a magyar helyzet” c. diplomamunkája és TDK dolgozata alapján íródott (Budapesti Corvinus Egyetem, konzulens: Baji Petra).

\section{ÖSSZEFOGLALÓ}

Annak ellenére, hogy Magyarországon a hálapénz kifejezetten elterjedt a szülészetben, kevés kutatás irányult ennek a kérdésnek a mélyebb vizsgálatára.

A cikkben ismertetett kvalitatív kutatás célja a szülészeti hálapénz előfordulásának, motivációjának, hatásainak feltárása különböző internetes fórumokon fellelhető, szülésen átesett nők tapasztalatait leíró bejegyzések és hozzászólások elemzésén keresztül.

Meghatározott fórumokról és blogokról 50 eset került véletlenszerüen kiválasztásra. Az adatgyüjtés a 2015.10.05. és 2016.03.01. közötti időszakban folyt. Ezek elemzését elöre meghatározott kritériumok alapján végeztük el.

Eredményeink szerint a vizsgált esetek több mint háromnegyedében fizettek hálapénzt a szülésért, átlagosan 52 ezer Ft-ot. Sokan választottak fogadott orvost, ami minden esetben maga után vonta a hálapénzfizetést. Az orvosválasztás és a hálapénzadás főbb motivációja a biztonságérzet és a megfelelő ellátás iránti igény volt, valamint az, hogy a fogadott orvos legyen jelen a szülésnél. Az ellátással való elégedettség és a hálapénzfizetés között nem találtunk egyértelmű kapcsolatot. További kutatásokra van szükség annak érdekében, hogy a hálapénznek az ellátás minőségére gyakorolt hatásait feltárjuk.

\section{SUMMARY}

In Hungary, informal payments are rather frequent in maternity care, however little evidence is available on this issue.

The objective of this qualitative study is to explore the prevalence, motivation and effects of informal payments in maternity care by analyzing comments and blog of women who delivered on online forums.

In the first round, online websites and forums were identified. After, 50 cases were randomly selected and analyzed based on pre-defined criteria.

In more than three-fourth of the cases, women or their families paid informally to the physician or other health care workers on average 52 thousand HUF. Many women had a chosen doctor, in which case payment was inevitable. The main motivation behind payments were the need for security and proper care, as well as the desire for the cho- sen doctor to be present at birth. We did not find association between satisfaction with services and informal payments. Further research is needed to obtain more information about the effect of informal payments on the quality of care.

Kulcsszavak: hálapénz, szülészet, egészségügy

Keywords: informal payments, Hungary, birth, health care

JEL: D12, I11, I18

DOI: $10.18530 /$ BK.2017.1.82

http://dx.doi.org/1018530/BK.2017.1.82

\section{Bevezetés}

A hálapénz ma is - a rendszerváltás után több mint húsz évvel - a magyar egészségügyi rendszer meghatározó eleme (Baji - Gulácsi, 2012). Hálapénznek (illetve informális kifizetésnek - angol terminológiával „informal payment”) tekintünk minden olyan nem hivatalos kifizetést és ajándékot, amelyeket az egészségügyi dolgozók kapnak a betegektől (Stepurko - Pavlova - Gryga et al, 2010). A magyar lakosság nagy része annak ellenére, hogy az egészségügyi ellátások jelentős része ingyenes, rendszeresen fizet az ellátásért informális csatornán keresztül, hálapénz formájában. A hálapénz különösen elterjedt a fekvőbeteg-ellátás területén, ahol a betegek mintegy fele fizet informálisan az egészségügyi személyzet számára (Baji - Pavlova - Gulácsi et al., 2014).

Egy nemzetközi kutatási program eredményei szerint 2010-ben a kórházi ellátásban részesülők közel fele (44\%) fizetett hálapénzt, átlagosan évi 37300 Ft-ot. Az 50 és 65 év közöttiek, valamint a 65 év felettiek fizettek a leggyakrabban (48 és 47\%), és a 65 év felettiek fizették a legmagasabb összeget ( $48654 \mathrm{Ft}$, szórás = $72699 \mathrm{Ft}$ (relatíve nagy)). Az orvosi ellátás esetében a fizetett hálapénz átlagosan évi $16900 \mathrm{Ft}$ volt, és az összeg a nagyon rossz egészségi állapotúak esetében volt a legmagasabb (23 194 Ft, szórás = 39336 Ft (relatíve nagy)) (Baji - Gulácsi, 2012).

A hálapénz meglehetősen egyenetlenül oszlik meg a különböző orvosi szakterületek és szakmák között (Mihályi, 2004). A Központi Statisztikai Hivatal adatai szerint 2014-ben a legnagyobb összeget a kórházi orvosok kapták (4,1 milliárd forint), utána következnek a házi- és szakorvosok (2,5 milliárd Ft), a fogorvosok (1,1 milliárd Ft), végül az ápolók, orvosi asszisztensek, mütősök (508 millió Ft) (KSH, 2015).

A szakirodalom szerint a hálapénz jelensége csökkenti az egészségügyi rendszer finanszírozásának átláthatóságát, veszélyezteti a szolgáltatók elszámoltathatóságát, továbbá az egészségügyi források nem hatékony felhasználásához vezet (Baji - Pavlova - Gulácsi et al, 2013). A hálapénz továbbá sérti az egyenlő hozzáférés elvét, hiszen a magasabb jövedelműek 
esetlegesen előnyt tudnak vásárolni maguknak (Kincses, 2007). A hálapénz növelheti a betegek kiszolgáltatottságát, mivel olyan szolgáltatást próbálnak vásárolni, amely nem definiált, semmilyen szerződésbe nincs foglalva, ezért nem kikényszeríthető (Kincses 2007, Solymosi, 2005).

\section{A hálapénz jelensége csökkenti az egészségügyi rendszer finanszírozásának átláthatóságát, továbbá az egészségügyi források nem hatékony felhasználásához vezet.}

A szakirodalomban vitatott a hálapénz motivációja. Egyesek szerint a betegek hálájuk kifejezéseképpen fizetik a hálapénzt, ahogy neve is sugallja, de a kutatások rámutatnak, hogy a hálapénz inkább ún. „fee for service” szerepet tölt be (Gaál - Evetovits - McKee et al, 2006). A betegek annak a reményében fizetnek, hogy valamiféle többletszolgáltatást (pl. gyorsabb sorra kerülést, több személyes figyelmet) kapnak pénzükért cserébe, vagy éppen attól félnek, hogy nem kapják meg a szükséges/megfelelő ellátást, ha nem fizetnek (Baji Pavlova - Gulácsi et al, 2015).

A hálapénzzel kapcsolatos attitűdöket vizsgáló tanulmányokból az derül ki, hogy a magyar lakosság és az orvostársadalom a hálapénzt szükséges rossznak tartja, melyre az egészségügyi dolgozók alulfinanszírozása miatt van szükség (Baji - Pavlova - Gulácsi et al, 2013). Annak ellenére, hogy egy nemzetközi felmérésben a válaszadók több mint 80 százaléka egyetértett azzal, hogy az orvosoknak, egészségügyi dolgozóknak adott hálapénzt vagy ajándékokat el kellene törölni, és hogy a hálapénz hasonlít a korrupcióhoz, a lakosság toleránsnak mutatkozott a hálapénzzel szemben, hiszen egy más módon feltett kérdésből kiderült, hogy a válaszadók többsége (52\%) közömbös vagy pozitív attitűddel rendelkezett a hálapénzzel kapcsolatban. Különösen igaz volt ez a fövárosiakra, a 65 év feletti korosztályra és az alacsony iskolai végzettségűekre (Baji - Pavlova - Gulácsi et al, 2013).

A Szinapszis Kft. 2009 őszén készített felmérést a magyarországi orvosok körében (Szinapszis, 2010). A felmérés eredménye szerint a hazai orvosok többsége (57\%) nélkülözhetetlennek tartja a hálapénzt az alacsony bérek miatt. Kis részük (6\%) gondolja úgy, hogy azállam a betegekkel pótoltatja ki az orvosok fizetését. Viszonylag magas azoknak az orvosoknak (43\%) az aránya, akik megalázónak tartják a beteg által adott pénzt, és 17 százalékuk egyáltalán nem ért egyet vele.

\section{Hálapénz a szülészetben}

A szülészet az egyik olyan szakterület, ahol a hálapénz kifejezetten elterjedt (Bognár - Gál - Kornai, 1999). Magyarországon a terhesgondozás és a szülés a társadalombiztosítás által finanszírozott ellátás. Ennek ellenére a TÁRKI kutatása szerint 2007-ben a megkérdezettek több mint fele (55\%) szerint kivétel nélkül mindenki (tehát tízből tíz ember) ad a szülészorvosnak hálapénzt (TÁRKI, 2007).
Egy 2011-es felmérés szerint (European Policy Brief, 2013) a közép- és kelet-európai országokban a terhesgondozás, illetve a szülészet finanszírozási problémákkal küszködik. Az elérhető források elosztása méltánytalan és szakszerütlen. Általában a vidéki területeket elavult berendezések, romlott infrastruktúra, orvossághiány jellemzi, szemben a fővárosokkal. A technológia nem megfelelő használata, a császár- és gátmetszés magas aránya, a hatástalan beavatkozások, illetve a nem betegközpontú ellátás mind megfigyelhetőek ebben a térségben. Mindezekkel magyarázható, hogy a hálapénz igen elterjedt ebben a régióban, különösen Magyarországon. Míg a tanulmány szerint Bulgáriában az állapotos nők 30 százaléka fizet az orvosoknak, addig Magyarországon és Ukrajnában körülbelül kétszer annyian.

\section{A közép- és kelet-európai országokban a terhesgondozás,}

\section{illetve a szülészet finanszírozási problémákkal küszködik.}

Annak ellenére, hogy a szülészeti hálapénz ennyire elterjedt, egyik hálapénzre irányuló kutatás sem foglalkozott kifejezetten ezzel a területtel. Éppen ezért e tanulmány célja a hálapénz jelenségének vizsgálata a szülészetben kvalitatív módszerekkel, különböző internetes oldalakon fellelhető (online fórumok és blogok), szülésen átesett nők tapasztalatait leíró bejegyzések és hozzászólások elemzésén keresztül. A kutatás a szülészeti hálapénz előfordulásának, motivációjának, hatásainak feltárására irányul, valamint a szülészeti hálapénzzel kapcsolatos vélemények, attitűdök vizsgálatára. Különös figyelmet fordítottunk a hálapénz és az ellátás minősége közötti összefüggések feltárására is.

\section{Módszertan}

A szülészet-nőgyógyászat területén a nők hálapénzzel kapcsolatos véleményének, a hálapénz szerepének, elterjedtségének vizsgálatára kvalitatív kutatási módszert alkalmaztunk. A kvalitatív kutatási kérdések feltáró jellegűek, amelyek elsősorban a hipotézisalkotásra irányulnak, nem pedig a mérésre, mint ahogy ez egy kvantitatív kutatás esetében elvárás (Corbin-Strauss, 2015). A kvalitatív kutatás alapvető célja az egyedi esetek kimenetelének magyarázata. A kutatás központi célkitüzései közé tartozik, hogy meghatározza bizonyos kimeneteleknek az okait. Azzal, hogy a vizsgálat az egyes esetekre vonatkozóan a kimenetelektől indul visszafelé, az okok felé, a kvalitatív kutatás „a következmények okait” kereső megközelítést tesz magáévá a magyarázat természetét illetően (Mahoney - Goertz, 2006).

\section{Mintavétel}

A mintavételi eljárás két lépésből állt. Első körben a mintába kerülő fórumok és blogok kerültek kiválasztásra, amelyek a szülészetben jelen lévő hálapénzzel foglal- 
koztak. Az adatbázisok kiválasztásánál fontos szempont volt, hogy a bejegyzések a hálapénzzel foglalkozzanak. Nem volt kizáró ok, ha az adott fórum nem kifejezetten a szülészetre vagy a hálapénz kérdésére specializálódott, amennyiben volt ezzel a témával kapcsolatos kategóriája. Összesen 10 internetes portál került be az adatbázisok körébe: 1) babaszoba.hu; 2) babanet.hu; 3) hoxa.hu; 4) gyakorikerdesek.hu; 5) divany. hu; 6) bboom.hu; 7) szulesvideok.info; 8) ursula.cafeblog.hu; 9) atlatszo.blog.hu; 10) fizettem.hu.

A bejegyzések két módon születtek. A hozzászólást írók vagy olyan cikkre, hírre reagáltak, ahol volt lehetőségük leírni a véleményüket, vagy egy másik felhasználó által feltett kérdésre válaszoltak, például „Mennyi hálapénzt szokás adni szülészorvosnak és szülésznönek mostanában?” Mind a cikkek, mind a kérdések témájukban kötődtek a szülészetben jelen lévő hálapénzhez.

A mintavétel következő lépése során véletlenszerűen kerültek kiválasztásra a vizsgált esetek. Kiválasztási kritérium volt, hogy az 1. táblázatban előre meghatározott elemzési szempontok közül legalább 5-re térjen ki a bejegyzés (a technikai szempontokat leszámítva). A mintába csak olyan hozzászólókat válogattunk be, akik saját tapasztalataikról számoltak be, tehát maguk szültek, vagyis a vizsgálat nem foglalkozik azokkal a bejegyzésekkel, amelyekben várandósok tesznek fel kérdéseket. Nem kerültek beválogatásra továbbá azok az esetek sem, ahol a hozzászólók nem a saját esetüket, hanem ismerőseik vagy rokonaik élményeit osztották meg.

A vizsgálatba végül összesen 50 eset került beválogatásra. Az esetek kiválasztása 2015.10.05. és 2016.03.01. között zajlott, de a bejegyzések keletkezésére vonatkozóan nem szabtunk időkorlátot. Mivel az adatgyüjtés és az elemzési szempontok kialakítása némileg párhuzamosan történt, ezért az adatgyủjtés addig zajlott, míg újabb szempont már nem merült fel, és a szempontok alkalmasak voltak az elemzésre is.

A bejegyzésekből, hozzászólásokból kinyert adatok, információk egy Excel táblázatban kerültek rendszerezésre. Minden megfigyelés külön sor, minden szempont külön-külön oszlopba tartozott.

\section{Elemzési szempontok}

A különböző fórumokon, blogokon található bejegyzéseket, hozzászólásokat előre meghatározott elemzési szempontok szerint vizsgáltuk. Az 1. táblázatban ismertetett elemzési szempontokat a szakirodalom és korábbi kutatások alapján alakítottuk ki (Stepurko - Pavlova - Gryga et al, 2010, Stepurko - Pavlova - Levenets et al, 2013). Minden egyes elemzési szempont jól meghatározható kutatási kérdéshez kapcsolódik, mint például a hálapénzfizetés gyakorisága, összege, attitűdök, motivációk vagy a hálapénznek a minőséggel való összefüggése.
1. táblázat A szakirodalom alapján meghatározott elemzési szempontok

\begin{tabular}{|c|c|}
\hline Elemzési szempontok & Vizsgathi kivant kerdeskör \\
\hline Adott-e az illeto halaptuzt a szalosstr? & 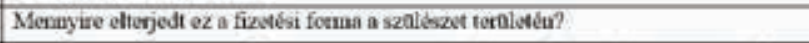 \\
\hline Fizetette a vizspilatokent valienuilyen & 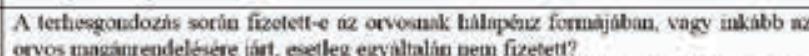 \\
\hline Ha ndoth, meriayi volt a hillapenz osszege? & 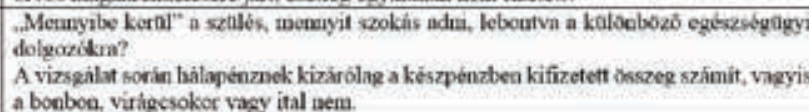 \\
\hline Milyen indifrtásbbol fizetett hallapkezz? & 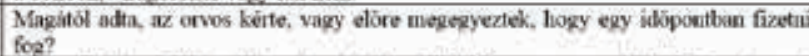 \\
\hline $\begin{array}{l}\text { Ha minga kezdeményezte, alkor mién adta, } \\
\text { mit vist ettôl? }\end{array}$ & 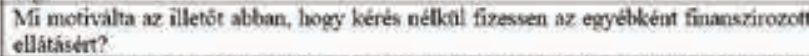 \\
\hline Makor adta oda az osszzeger? & 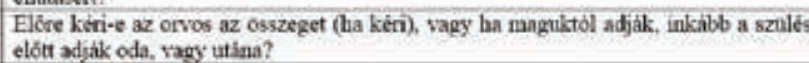 \\
\hline 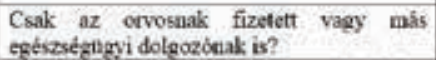 & 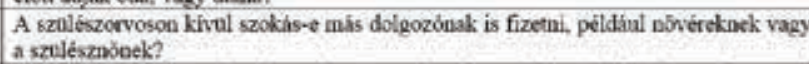 \\
\hline 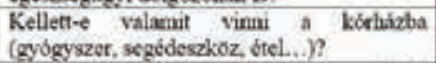 & 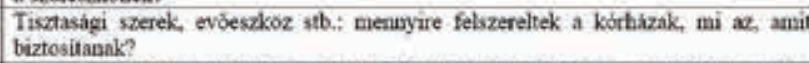 \\
\hline $\begin{array}{l}\text { Vollee szemelyes kapesolath, orvos } \\
\text { ismeróse? }\end{array}$ & 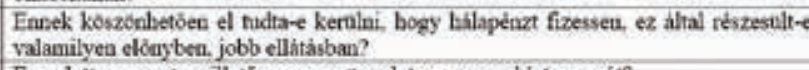 \\
\hline Ki vezette le as szaless? & \\
\hline $\begin{array}{l}\text { Malyen úton szult? } \\
\text { Elézedett wolter az ellátással? }\end{array}$ & 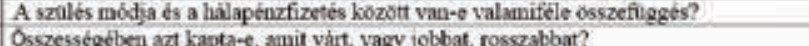 \\
\hline $\begin{array}{l}\text { Milyen batissal volt a hallapenrfizetés nem } \\
\text { fizetes az ellatas minsogegere? }\end{array}$ & 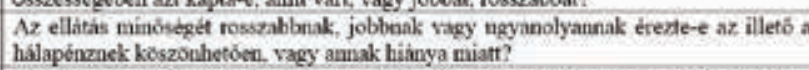 \\
\hline 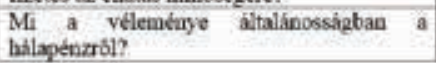 & 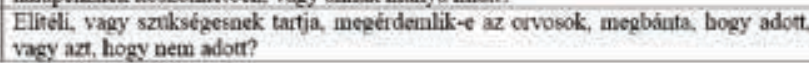 \\
\hline
\end{tabular}

Forrás: Saját táblázat

A táblázatban bemutatott szempontokon kívül további technikai szempontok is rögzítésre kerültek:

- Melyik fórumról származik a hozzászólás/bejegyzés?

A honlap címe

Melyik évben született a bejegyzés/hozzászólás?

Melyik évben történt a szülés?

Idézet forrása, link

Az adatgyüjtés során a vizsgált kérdéskörök a bejegyzésekhez igazodva folyamatosan kiegészültek, változtak. Fontos megjegyezni, hogy egy szempont sem került ki a vizsgálandók köréből, függetlenül attól, hogy rendelkezésre állt-e megfelelő mennyiségű adat a kérdés megválaszolásához. Fontos információnak tartjuk ugyanis azt is, ha egyes kérdésre nem tértek ki az elemzett bejegyzések, hozzászólások.

\section{Eredmények}

Összesen 50 eset került kiválasztásra. A legfrissebb tapasztalatleírás (bejegyzés) 2013-ban került bejegyzésre, míg a legrégebbi 2002-ben. A legrégebbi hozzászólás 2006-ban íródott, míg 
a legutóbbi 2014-ben. Az 50 vizsgált esetből 17-en (34\%) adták meg a szülés évét, a többség, 33-an (66\%) nem közölték ezt.

\section{A hálapénzfizetés gyakorisága}

A vizsgált esetek közül 39-en (78\%) írták, hogy hálapénzt fizettek a szülésért valamely egészségügyi dolgozónak. Mindösszesen 11-en (22\%) nyilatkoztak úgy, hogy nem fizettek hálapénzt (1. ábra), ebből a 11 esetből egyvalaki azért nem fizetett, mert az orvos nem fogadta el az összeget. „Amikor át akartam adni neki a boritékot, ezt mondta: „Maguknak most nagyobb szükségük van erre a pénzre, mint nekem.”

\section{1. ábra: A hálapénzfizetés gyakorisága}

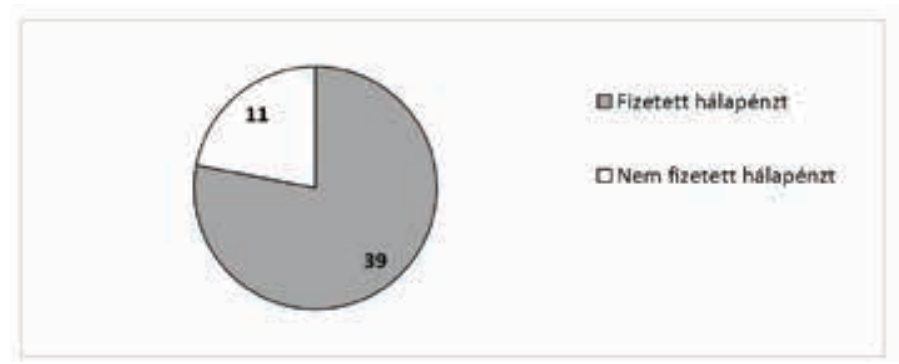

Forrás: Saját ábra

Azok közül, akik fizettek az ellátásért, a legtöbben, 25-en ( 64\%) csak az orvosnak fizettek. A második leggyakoribb esetben 11 kismama ( 28\%) az orvos mellett a szülésznőnek is fizetett hálapénz formájában. Mindösszesen 2-en ( 5\%) voltak, akik csak a szülésznőnek fizettek, és egyvalaki ( 2\%) a szülésznőnek és a csecsemős nővérnek adott pénzt (2. ábra).

\section{2. ábra: Fizetett hálapénz megoszlása}

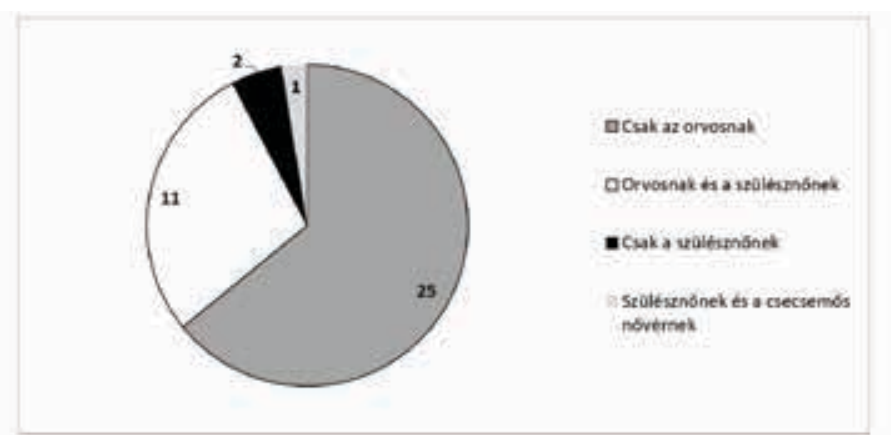

Fogadott orvos, hálapénz

A bejegyzések alapián megállapítható, hogy az esetek többségében, 30-an (60\%) fogadtak orvost (3. ábra). Ebből a 30 esetből 2 esetben a fogadott orvos éppen akkor ügyeletes volt, egy esetben pedig a páciensnek úgy volt fogadott orvosa, hogy megkérte az orvost, akihez SZTK-ba járt rendelésre, hogy vezesse le a szülést, így végül csak azért fizetett. Azokban az esetekben, ahol a pácienseknek fogadott orvosuk volt, kivétel nélkül mindannyian fizettek hálapénz formájában. Ennek az az oka, hogy úgy gondolják, a folyamatos készenlétet, a nagyobb figyelmet meg kell fizetni, illetve fontos, hogy ne egy idegen orvos legyen mellettük a szüléskor (2. táblázat).

\section{2. táblázat: Idézetek online adatbázisról - fogadott orvos}

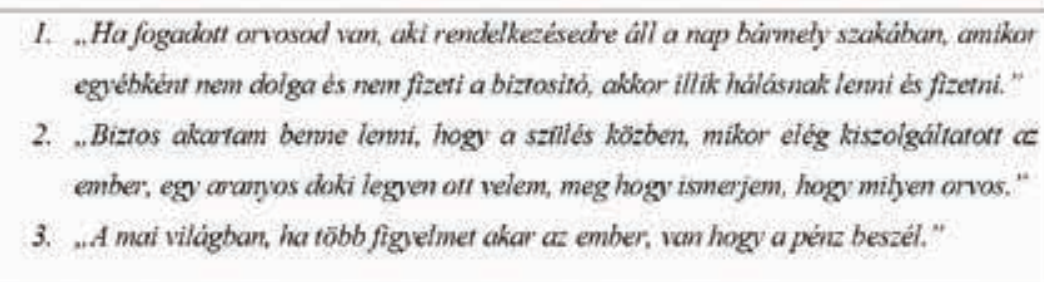

Forrás: Saját táblázat

Az összes esetből 13-an (26\%) döntöttek úgy, hogy nem fogadnak orvost, és az ügyeletes orvosnál szülnek (3. ábra). Ebbe a 13 esetbe tartozik 5 olyan eset, aki fizetett, és 8 olyan, aki nem fizetett hálapénzt. A maradék 7 (14\%) esetben nem derült ki egyértelműen, hogy az illetőnek volt-e fogadott orvosa, vagy nem. Ebből a 7 esetből 4-en adtak, 3 -an pedig nem adtak hálapénzt, és ebbe tartozik az az egy eset is, akitől az orvos nem fogadta el a pénzt.

\section{3. ábra: Szülést levezető orvosok megoszlása (esetek száma)}

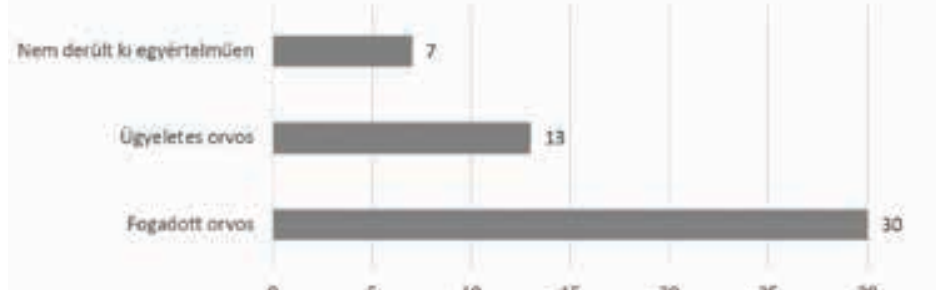

Forrás: Saját ábra 


\section{A hálapénz összege}

A hálapénz összegét illetően a 39 esetből 26-an ( 66\%) megadták, 13-an ( 33\%) nem írták meg az összeg nagyságát. A hálapénz összege átlagosan körülbelül 52000 forintra tehető, a legalacsonyabb összeg 15000 forint, a legmagasabb 120000 forint volt (80 000 az orvosnak, 40000 a szülésznőnek) (4. ábra). A legtöbben 21000 és 40000 forint közötti összeget fizettek, amelybe kizárólag a hálapénz formájában, valamely egészségügyi dolgozónak fizetett összeg tartozik bele, az orvos magánrendelésén, terhesgondozás során fizetett nem. A hozzászólásokból az derül ki, hogy a kifizetett összeg nagyságára leginkább a páciens anyagi helyzete van hatással.

\section{4. ábra: A hálapénz összegének nagysága (esetek száma)}

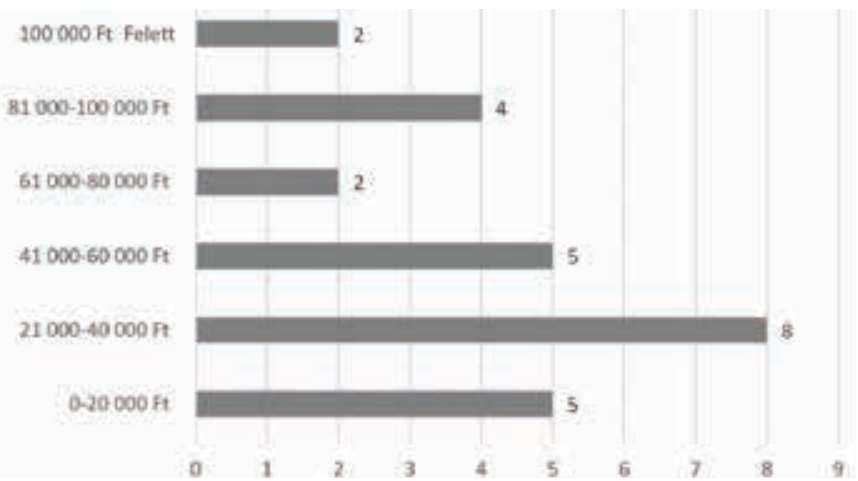

Forrás: Saját ábra

Magánrendelésre az esetek közül 23-an jártak, jellemzően azok, akiknek fogadott orvosuk volt. Ebből 11-en írták le az összeget, amely 3000 és 11000 forint között mozgott alkalmanként, ez átlagosan a 11 esetet nézve 7636 forintot jelent alkalmanként. Fontos megjegyezni, hogy a magánrendelésen fizetett összeg nem minősül hálapénznek, mivel hivatalos magánrendelésről van szó. Viszont, ha egy terhesgondozás és szülés kapcsán fellépő teljes anyagi terhet szeretnénk látni, akkor ezeket az összegeket is figyelembe kell venni.

A hálapénzadás időpontja, kezdeményezője

A pénz átadásának időpontjára a bejegyzésekben nem fordítottak nagy hangsúlyt. Nem tértek ki rá egyértelműen, csak néhány kirívó esetben, jellemzően, amikor az orvos megmondta, hogy mennyit kér.

Általánosságban elmondható, hogy a szülészek többsége nem mondja meg, mennyit kér, hiszen ezt hivatalosan nem is teheti meg. „Még jóval a szülés elött rákérdeztem, hogy Nála mennyibe kerül a szülés, ö azt mondta, hogy mindenki maga döntse el, nincsenek fix tarifái." A bejegyzések alapján megállapítható, hogy manapság létezik egy látens szabály, mely szerint a terhesgondozás során alkalmanként fizetett vizitdí tízszeresét illik adni a szülésért. A kismamák többsége ezzel tisztában van, és a legtöbb esetben így is tesznek, már ha anyagilag megtehetik. A vizsgált esetekből 5 esetben biztosan eszerint cselekedtek.

Olyan esetről is beszámoltak azonban, amikor az orvos konkrétan megmondta, hogy mekkora összeget kér a szülés levezetésért. „Azt mondta, hogy a szülésért 130 000-t kér, cserébe akáréjjel is bejön stb....”; „elöre meg volt beszélve, h ennyi a sima szülés is, császár is.” Négy bejegyzésből derült ki egyértelmüen, hogy az orvos kérte a pénzt, egy esetben pedig, hogy a szülésznő megmondta, hogy mennyit szokott kapni. Akik magánrendelésre jártak, általában előre érdeklődtek az orvostól az összeget illetően, és feltételezhetően a szülés után adták oda. Voltak olyan esetek is, ahol a páciens magától fizetett a kontrollvizsgálat alkalmával vagy varratszedéskor.

\section{Az elégedettség és a hálapénz}

Azok közül, akik nem fizettek (11 esetből) 7-en számoltak be arról, hogy ennek semmilyen negatív következménye nem lett. Két esetben olvashattunk panaszt a páciens részéről. Az egyik esetben arra panaszkodott a páciens, hogy sokat váratták, de ennek ellenére az ellátást ő is megfelelőnek ítélte meg. Egy másik esetben, a kismama elégedetlen volt az ellátással, ő úgy nyilatkozott, hogy a szülést követően sorsára hagyták, és legközelebb a jobb elbánás érdekében megfontolja, hogy ö is fizetni fog. „Első reakciónk a testvérröl való lemondás gondolata volt, ám végül úgy döntöttünk, ha vállalunk még gyermeket, mindenképp másik kórházban fogok életet adni neki, stervezzük az anyagi juttatások "emelését"."

Azok közül, akik fizettek, szinte mindenki elégedett volt az ellátással, és nem bánták meg, hogy fizettek, legtöbben úgy vélték, hogy megérte, vagy muszáj volt. Az orvosok kedvesek és figyelmesek voltak, és bármikor hívhatták őket. Egyvalaki volt kifejezetten elégedetlen, annak ellenére, hogy fizetett hálapénzt. Úgy érezte, hogy az orvos meg sem érdemelte, mivel hagyta őt szenvedni. A többi esetben negatív élményről nem számoltak be.

\section{A hálapénzzel kapcsolatos attitüdök}

Az 50 vizsgált esetből 22-en (44\%) írtak a hálapénzzel kapcsolatos attitüdjükről, a hálapénzről alkotott véleményükröl. Ezek között volt elfogadó és elítélő megnyilvánulás egyaránt (3. táblázat). A bejegyzések hangvételéből itélve, és abból, hogy a többség fizetett hálapénzt, a hálapénz iránti attitüd inkább mondható elfogadónak vagy közömbösnek, mint elítélőnek. Többen azonban egyáltalán nem tértek ki arra, hogy miként viszonyulnak a kérdéshez.

\section{A hálapénz iránti attitüd inkább mondható elfogadónak vagy közömbösnek, mint elítélőnek.}

Négy esetben írták egyértelműen, hogy az orvosok megérdemlik a hálapénzt, egy esetben fogalmaztak úgy, hogy illik hálásnak lenni. Voltak olyan kismamák is, akik bár elutasították, 
vagy nem tartották etikusnak a hálapénzt, mégis fizettek. Továbbá voltak, akik úgymond „kényszerből” tették meg, mivel csak így lehettek biztosak abban, hogy az orvostól megkapják a kellő figyelmet. Többen nyilatkoztak úgy, hogy a szülő nők, illetve általánosan a betegek is tehetnek arról, hogy ilyen helyzet alakult ki, azáltal, hogy a páciensek egymást próbálják túllicitálni az összegeket illetően.

Voltak olyan esetek, ahol a kismamák elutasítóak voltak a hálapénzzel kapcsolatban, és nem is fizettek hálapénzt. Ezt azzal magyarázták, hogy „tb-járulék formájában már előre fizettek az ellátásért, akkor minek tennék meg még egyszer”, illetve, hogy „az orvosnak az a dolga, hogy levezesse a szülést".

\section{3. táblázat: Idézetek az online adatbázisokról - attitüdök, elégedettség}

1. ..Szerintem amigy megèrdemlik (a fỏ, odaftgyelö ês kẻszsẻges onvosok) ezt a pènzt, nagyon sok myomás nehezedik räjuk, alllandóan kẻszenlètben kell lennitïk mind szellemileg, mind fizikailag. "

2. „És attól finggetlenill, hogy én adtam pènzt, és hâläs is vagyok dokinak is, meg szülèszzônek is, egyáhalän nem normälis hogy hälapènzt fizetünk!!!"

3. ....èn is fizettem az orvosnak, mert igy éreztem azt, hogy törö́ni is fog majd velem a doki."

4. ..A beregek vastagon benne vamnak abban, hogy ez az äldatian helyzet kialakult"

5. .Engem nagyon feldĭhit az az arcátlanság, amivel az orvosom szó szerint kicsikiraja a pénzt az emberböl"

6. . ¿̇gy vagyok vele, hogy marha nagy pénzeket vonnak le a fizumból tb jogcimen"

7. a. annak ellenére, hogy nem volt fogadott onvosom, tényleg ùgy bántak wetem, mimt egy himes tojässal."

Forrás: Saját táblázat

\section{Egyéb eredmények}

Két olyan elemzési szempont volt, a melyre egyáltalán nem tértek ki a kismamák a bejegyzésekben, így az azokhoz kapcsolódó kutatási kérdések megválaszolására nem volt mód. Az egyik, hogy kellett-e valamilyen eszközt, gyógyszert a kórházba vinni. Ennek esetlegesen az lehet az oka, hogy a páciensek tisztában vannak a kórházi állapotokkal, és természetes számukra, hogy kérés nélkül is visznek tisztasági szereket, erről külön nem számolnak be. A másik szempont, amelyre szintén nem tértek ki a bejegyzések, hogy volt-e az illetőnek orvos ismerőse, és ezáltal jobb helyzetbe került-e a páciens. Ehelyett viszont a „fogadott orvos” jelentőségéről többen is beszámoltak.

Továbbá kevesen tértek ki a szülés módjára, leginkább császármetszés esetében.
Így nem volt alkalmunk megvizsgálni az összeg nagysága és a szülés módja közti összefüggéseket. Néhány esetből következtethetünk arra, hogy eltérőek lehetnek a „tarifák”, viszont a beszámolók szerint sok esetben hirtelen, az utolsó pillanatban dőlt el, hogy császármetszésre kerül sor, ezért az orvosok a legtöbb esetben erre nem határoztak meg külön árat. A kérdés megválaszolása szintén további kutatást igényel másik módszer alkalmazása mellett.

\section{Az eredmények megbeszélése és konklúzió}

Kvalitatív kutatásunk keretében a szülészet-nőgyógyászat szakterületén jelen lévő hálapénz jelenségét térképeztük fel 50 kiválasztott esetet vizsgálva. A kutatás célja a szülészeti hálapénzfizetés elterjedésének, motivációjának feltárása volt, valamint a hálapénzzel kapcsolatos attitűdök, vélemények, tapasztalatok elemzése. A vizsgálódás több hónapon keresztül, online fórumokon és blogokon zajlott elöre meghatározott kutatási szempontok alapján. A megfigyelt esetek alapján megállapítható az is, hogy az elmúlt években egyre többen fogadtak és fizettek az orvos mellett szülésznőt is.

A kutatás főbb megállapításait az alábbi pontokban foglaljuk össze.

Majdnem mindenki fizet hálapénzt a szülésért

Az általunk vizsgált esetek 78 százalékában a kismama vagy családja fizetett az orvosnak vagy más egészségügyi dolgozónak azért az ellátásért, amelyre ingyen is jogosult lenne. Ez megerősíti a korábbi kutatások eredményeit, miszerint Magyarországon az állapotos nők többsége fizet hálapénz formájában az orvosoknak (European Policy Brief, 2013).

\section{Az esetek 78 százalékában a kismama vagy családja fizetett az orvosnak vagy más egészségügyi dolgozónak azért az ellátásért, amelyre ingyen is jogosult lenne.}

Kiderült az is, hogy akinek anyagi helyzete megengedi, nem sajnálja „meghálálni” az orvos vagy más dolgozó fáradozásait. Így néhány esetben a csak a szülésért fizetett összeg a 100000 forintot is elérheti vagy meghaladhatja. Összehasonlításképpen, Magyarországon a minimálbér összege 2015-ben bruttó 333 euró volt, ami 310-es átváltási árfolyammal számolva körülbelül 103230 forint (Eurostat, 2015). A környező országokban, például Szerbiában 500 euró volt a legmagasabb kifizetett összeg (Arsenijevic - Pavlova - Groot, 2014), ami 155000 forint, szintén 310-es árfolyamon számolva.

Annak alapján, hogy a vizsgált esetek körülbelül háromegyede fizetett hálapénzt, és hogy kevés volt a negatív megnyilvánulás a fizetéssel kapcsolatban, arra lehet következtetni, hogy a kismamák elfogadóak vagy inkább közömbösek a hálapénzzel szemben. Ezt támasztják alá a lakosság körében végzett kutatási eredmények is (Baji - Gulácsi, 
2012, Baji - Pavlova - Gulácsi et al. 2013). Voltak olyan esetek is, ahol annak ellenére fizettek a kismamák, hogy nem értettek egyet azzal, amit tesznek, vagy éppen nem tartották azt etikusnak. Vagyis még azok is hajlandóak voltak fizetni, akik inkább negatív attitűddel rendelkeztek a hálapénzzel kapcsolatban.

\section{A többség fogadott orvos mellett dönt, ami maga után vonja a hálapénzfizetést}

Az Ukrajnában végzett kutatás (Stepurko - Pavlova - Levenets et al, 2013) eredményeihez hasonlóan Magyarországon is meg lehet különböztetni a páciensek két csoportját, az egyik, akinek volt fogadott orvosa, és előre megegyeztek vele a szülés levezetésében, a másik csoport pedig, akiknek nem volt fogadott orvosuk, így ügyeletes orvosnál szültek. Ebben az esetben az ügyeletes orvosok vagy a szülés után, vagy kontrollvizsgálat alkalmával kaptak hálapénzt, ha kaptak.

Az általunk vizsgált esetek 60 százaléka (úgy, hogy az esetek 14\%-áról nem volt egyértelmű információ) fogadott orvos mellett döntött, és ezekben az esetekben kivétel nélkül mindenki fizetett hálapénzt a szülésért. Az orvosfogadás - és ezzel együtt a hálapénz fizetése - többféle módon magyarázható a bejegyzések és hozzászólások alapján: egyrészt a biztonságérzet és a megfelelő, minőségi ellátás igényével. Sokan féltik saját és gyermekük életét, többen nyilatkoztak úgy, hogy a komplikáció elkerülése érdekében érdemes fizetni. Másrészt az orvos személye is biztonságot nyújthat a kismamának, megnyugtatóbb, ha olyan ember van ott vele, akivel már korábban találkozott, vagy jókat hallott róla. A kismamák közül többen vélekedtek úgy, hogy ha az orvos müszakián kívül vezeti le a szülést, akkor azt illik megfizetni. A bejegyzések szerint, ha valaki orvost választ magának, „az már önmagában ok a fizetésre, hiszen a fogadott orvos általában számít a pénzre, a páciensek pedig el sem tudják képzelni, hogy ne honorálják a választott orvos munkáját", még akkor is, ha nem feltétlenül értenek egyet vele. Megjegyzendő, hogy a nők nemcsak hálapénz formájában fizettek a választott orvosnak, hanem a legtöbb esetben az orvos magánrendelésére is jártak a terhesgondozás során, ami mondhatni, feltétele annak, hogy valakinek fogadott orvosa legyen. Így a bejegyzések szerint nem volt kérdéses, hogy az állami kórházban történő szülés levezetését a páciens honorálja.

\section{Az elégedettség és a hálapénzfizetés között nem találtunk egyértelmü kapcsolatot.}

Mindez persze nem azt jelenti, hogy hálapénz nélkül a kismamák az ügyeletes orvostól nem kapják meg a kellő figyelmet és ellátást, hiszen a vizsgált esetek között is találtunk ellenpéldát, amikor komplikációmentesen lezajlott a szülés, és elégedetten távoztak a kórházból a kismamák úgy, hogy senkinek nem fizettek semmit. Arra azonban lehet következtetni, hogy a várandós nők többsége nem bízik a társadalombiztosítás által nyújtott ellátás minőségében.

\section{A hálapénz összege a terhesgondozási vizit árának tízszerese}

A témával kapcsolatban lényeges kérdés, hogy mi határozza meg a hálapénz összegét. A vizsgálat alapján megállapítható, hogy ezt több minden befolyásolja, de leginkább meghatározó a páciens anyagi helyzete, másodsorban pedig a szokás vagy szabály (pl. a terhesgondozás során alkalmanként fizetett díj tízszerese). Az ár kialakulása mindenképpen fontos kérdés egy olyan piacon, ahol a szolgáltatásért nem lehet pénzt kérni, így az árakat sem lehet kihelyezni vagy nyilvánosságra hozni, ezáltal összehasonlítani. Voltak olyan esetek, amikor a páciens hiába tudta, hogy mennyit illik adni, mégsem engedhette meg magának anyagilag, és ilyenkor egy általa gondolt összeget fizetett.

\section{Egyre gyakrabban fizetnek a szülésznőknek is}

A megfigyelt esetek alapján megállapítható az is, hogy az elmúlt években egyre többen fogadtak az orvos mellett szülésznőt. Sőt, vannak olyan kismamák is, akik csak szülésznőt fogadtak. A bejegyzésekből kiderült, hogy a szülésznőnek adott hálapénz összege jóval alacsonyabb, mint az orvosnak adott hálapénz. Az 50 vizsgált esetből 13-an adtak pénzt a szülésznőnek is, ebből 9-en közöltek adatot az összegre vonatkozóan, ami 5000 és 45000 forint között mozgott. Vagyis továbbra is az orvosok kapják a legnagyobb összegeket az egészségügyi dolgozók közül, annak ellenére, hogy előfordul, hogy - a beszámolók szerint - a szülésznők többet segítenek a szülés során.

\section{Kérdéses az ellátásra gyakorolt hatás}

Az elégedettség és a hálapénzfizetés között nem találtunk egyértelmű kapcsolatot. Voltak, akik nem fizettek hálapénzt, mégis elégedettek voltak az ellátással, míg ennek az ellenkezőjét is megfigyelhettük. Továbbá a szülés módja, valamint a hálapénz öszszefüggéséről kevés adat állt rendelkezésre ahhoz, hogy megbízható következtetéseket vonjunk le. A hálapénz és az ellátás minősége közötti összefüggések feltérképezése további vizsgálatokat igényelne, esetlegesen kérdőíves kvantitatív kutatás formájában.

\section{Limitációk}

Fontos megjegyezni, hogy a kutatásunk kvalitatív jellegü, a kiválasztott minta nem reprezentatív az országban szülő nőkre nézve. A bejegyzések, hozzászólások internetes fórumokról származnak, a mi több okból is szelekciós torzításhoz vezethet. Egyrészt az internethasználat és internet-hozzáférés egyenlőtlensége miatt. Előfordulhat továbbá, hogy elsősorban azok a kismamák számolnak be tapasztalataikról, akik vagy nagyon pozitív vagy nagyon negatív tapasztalatokat szereztek, közülük is azok, akik hajlandóak 
voltak nyilvánosan megosztani tapasztalataikat az interneten. Ezen limitációk figyelembevételével azonban úgy gondoljuk, hogy a szülészeti hálapénz témájában kutatásunk hiánypótló, és új evidenciákkal szolgál, mely további kutatásokat alapozhat meg.

\section{Konklúzió}

Összességében elmondható, hogy a blogok, fórumok olvasása során azt tapasztaltuk, a várandós nők/kismamák sok információt osztanak meg egymással az online felületeken a kórházakkal, orvosokkal és a hálapénzzel kapcsolatban. Néhányan meglepő őszinteséggel írták le saját jó és rossz tapasztalataikat, amit vélhetően más körülmények között - például egy kérdőíves vizsgálat keretében - nem tettek volna meg, illetve nem tudtak volna részletezni.

A föbb eredményeket összefoglalva, azáltalunk vizsgált esetek több mint háromnegyedében számoltak be arról, hogy a kismama vagy családja fizetett hálapénzt a szülésért az orvosnak vagy más egészségügyi dolgozónak. A beszámolók szerint a szülésért fizetett összeg gyakran eléri vagy meg is haladja a 100000 forintot. Az általunk vizsgált esetek többségében a család fogadott orvos mellett döntött, ekkor kivétel nélkül minden esetben fizettek hálapénzt. Az orvosválasztás és a hálapénzadás főbb motivációjaként egyrészt a biztonságérzet és a megfelelő, „minőségi” ellátás igényét jelölték meg, aminek legfontosabb tényezője az, hogy a választott orvos legyen jelen a szülésnél. A bejegyzések alapján a hálapénz iráni attitűd inkább mondható elfogadónak vagy közömbösnek, mint elítélőnek. Voltak, akik úgy vélekedtek, hogy az orvosok megérdemlik a hálapénzt, mások, bár elutasították, vagy nem tartották etikusnak a hálapénzt, mégis fizettek. Továbbá voltak, akik úgymond „kényszerből” tették meg, mivel csak így lehettek biztosak abban, hogy az orvostól megkapják a kellő figyelmet. A beszámolók alapján az ellátással való elégedettség és a hálapénzfizetés között nem találtunk egyértelmű kapcsolatot. Voltak, akik nem fizettek hálapénzt, mégis elégedettek voltak az ellátással, míg ennek az ellenkezőjét is megfigyelhettük. Más minőségi paraméterek - pl. beavatkozások, a szülés módja stb. - és a hálapénz összefüggéséröl kevés adat állt rendelkezésre ahhoz, hogy megbízható következtetéseket vonjunk le. A hálapénz és az ellátás minősége összefüggésének feltérképezése azonban kiemelten fontos lenne ahhoz, hogy informálódjunk a hálapénznek az ellátás minőségére gyakorolt esetleges pozitív vagy negatív hatásairól, amiről jelenleg nem állnak rendelkezésre evidenciák. Ehhez azonban további kvantitatív kutatások szükségesek.

\section{IRODALOMJEGYZÉK}

Arsenijevic J. - Pavlova M. - Groot W. (2014) : Shortcomings of Maternity Care in Serbia, BIRTH 41:1

Baji P. - Pavlova M. - Gulácsi L. - Groot W. (2015): Does the Implementation of Official USer Charges Help to Eradicate Informal Payments - Lessons to be Learnt from the Hungarian Experience. Front Public Health. 2015; 3: 181.

Baji Petra - Gulácsi László (2010): Beteg Önrész - A lakosság fizetési hajlandósága az egészségügyi szolgáltatásokért [Patient payments - willingness of the Hungarian population to pay for health care services]. Esély [Chance], 2010 (4): pp. 106-117. Online: http://www.esely.org//kiadvanyok/2010_4/05baj.lindd.pd, Letoltés ideje: 2017. január 30.

payments and willingness of fontingent valuation study Eur J Health the Hungarian population to pay formal fees
Econ15(8):853-67.10.1007/s10198-013-0531-y

Online: https://www.ncbi.nlm.nih.gov/pubmed/23989982, Letöltés ideje: 2017. január 30.

Baji Petra - Gulácsi László (2012): A helyzet változatlan - egy reprezentatív kérdóives felmérés eredményei a magyar lakosság hálapénz-fizetési szokásairól és a hálapénz megiteléséról [ The situation has not changed - Results of a representative survey on (1) $30.30-41$.

Baji P. - Pavlova M. - Gulácsi L. - Groot W. (2013) : Exploring consumers' attitudes towards informal patient payments using the combined method of cluster and multinomial regression analysis - the case of Hungary. BMC Health Serv Res (2013) 15(13):62.10.1186/1472-6963-13-62

Tov/pmc/articles/PMC3606140/, Letöltés ideje: 2017. január 30. Bognár Géza - Gál Róbert Iván - Kornai János (1999): Hálapénz a Magyar Egészségügyben, TÁRKI, Budapest Corbin J. - Strauss A. (2015): A kvalitatív kutatás alapiai, L'Harmattan, Budapest

European Policy Brief (2013): The price of childbirth, out-of-pocket payments for maternity care in Central and Eastern Europe Online: https://ec.europa.eu/research/social-sciences/pdf/policy_briefs/brief_asspro_maternity_care_in_cee_countries.pdf

Eurostat National minimum wages in the EU,Monthly minimum wages in euro varied by 1 to 10 across the EU in January 2015 Eurostat National minimum wages in the EU, Monthly minimum wages in euro varied by 1 to 10 across he EU in January 2015
Online: http:///ec.europa.eu/eurostat/documents/2995521/6652357/3-26022015-AP-EN.pdf, Letöltés ideje: 2017 . január 30. Gaál P. - Evetovits T. - McKee M. (2006): Informal payment for health care: evidence from Hungary. Health Policy, 77(1): pp. 86-102. Online: https://www.ncbi.nlm.nih.gov/pubmed/16140416, Letöltés ideje: 2017. január 30 . Gaal P. - McKee M.. Fee-forservice or donation? Hungarian perspectives on informal payment for health care. Social Science and Medicine. 2005 Apr;60 (7): pp. 1445 - 57. Review.

Online: http//wwwkincsesgyula hu/dok mindig nem utoljára. Egészségügyi Stratégiai Kutatóintézet Központi Statisztikai Hivatal (2015): Statisztikai Tükör

Online: http://www.ksh.hu/docs/hun/xftp/stattukor/halapenz.pdf, Letöltés ideje: 2017. január 30. Mahoney J. - Goertz G (2006): Mese ket kulturarol: a kvantitativ es a kvalitativ kutatási módszerek összevetése

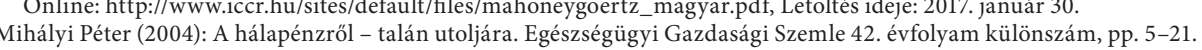
Solymosi Tamás (2005): Mai magyar egészségügy: helyzetelemzés és kibontakozás Védegylet, Budapest

Online: http://mek.oszk.hu/10000/10025/10025.pdf, Letöltés ideje: 2017. január 30.

Stepurko T. - Pavlova M. - Levenets O. - Gryga I. - Groot W. (2013): Informal patient payment in Kiev Ukraine, Int J Health Plann Mgmt 2013 (169-187) line: http://www.readcube.com/articles/10.1002/hpm.2155?r3 referer=wol\&tracking action=preview click\&show_checonlinelibrary.wiley.com\&purchase_site_license=LICENSE_DENIED_NO_CUSTOMER, Letöltés Stepurko T. - Pavlova M

M. - Gryga I. - Groot W. (2010): Empirical studies on informal patient payments for health care services: Online: https://www al review of research methods and instruments, BMC Health Services Research 2010 Szinapszis Kft. (2010): Orvosaink a hálapénzrőll. Online:

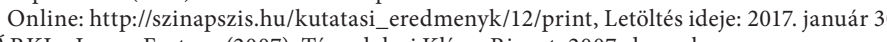

Online: http://www.tarki.hu/hu/news/2007/kitekint/20071220.html, Letöltés ideje: 201. január 30 